\title{
Pengembangan Teori Ring Mobile Application (Terima App): Media pembelajaran berbasis android untuk meningkatkan aksesibilitas pembelajaran Teori Ring
}

\author{
Sri Suryanti ${ }^{1}$, Deni Sutaji ${ }^{2}$ \\ Universitas Muhammadiyah Gresik ${ }^{1,2}$ \\ srisuryanti@umg.ac.id
}

\begin{abstract}
Abstrak
Pengembangan aplikasi berbasis android sangat berkembang pesat akhir-akhir ini, lebih dari 96\% masyarakat Indonesia menggunakan smartphone android. Sedangkan di dunia, lebih dari $80 \%$ dari 104 negara menunjukkan bahwa kaum muda menggunakan smartphone android. Permasalahan pembelajaran Aljabar abstrak di Indonesia adalah kurangnya media pembelajaran untuk bidang aljabar abstrak, yang salah satunya adalah Teori Ring. Media pembelajaran untuk mata kuliah Teori Ring selama ini masih sangat terbatas. Dalam penelitian ini, kami mengembangkan Teori Ring Mobile Application yang merupakan media pembelajaran Teori Ring berbasis android. Hasil validasi media yang dilakukan dalam tiga tahapan yaitu validasi ahli materi, validasi ahli media, dan validasi oleh pengguna, keseluruhan menunjukkan hasil yang positif. Selanjutnya kontribusi media ini dalam meningkatkan aksesibilitas pembelajaran dapat disimpulkan bahwa media ini memiliki tingkat aksesibilitas yang tinggi.
\end{abstract}

Kata kunci: Teori Ring, Mobile aplikasi, Aksesibilitas pembelajaran

\begin{abstract}
Android-based application development has been growing rapidly lately, more than $96 \%$ of Indonesian people use an Android smartphone. Whereas in the world, more than $80 \%$ of 104 countries show that young people use Android smartphones. The problem of abstract Algebra learning in Indonesia is the absence of readable learning media for the field of abstract algebra, one of which is the Ring Theory. Learning media for Ring Theory courses have been very limited. In this study, we developed the Ring Theory Mobile Application which is an Android-based learning media. The results of media validation which consisted of three types, namely material expert validation, media expert validation, and user validation, all showed positive results. Furthermore, the contribution of this media in improving learning accessibility can be concluded that this media has a high level of availability.
\end{abstract}

Keywords: Ring Theory, Mobile Application, Accessibility of learning

\section{PENDAHULUAN}

Internet telah hampir mengubah sisi kehidupan manusia (kurniawan, 2017), mencapai 4 milyar pengguna internet di dunia pada tahun 2017 (vpnMentor, 2018). Estimasi oleh Ketua Eksekutif Google Eric
Schmidt menyatakan bahwa pada tahun 2020 mendatang semua populasi di dunia akan terhubung ke internet. International Telecommunication Union (ITU) melaporkan bahwa $80 \%$ remaja di 104 negara menggunakan smartphone. Pada 
tahun 2016, banyaknya pengguna smartphone di dunia mencapai 7,5 milyar (Perwanden, 2016). Sedangkan di Indonesia, pengguna smartphone mencapai $25 \%$ dari total populasi dan bertambah 6 juta pertahun (ScientiaMobile, 2017).

Indonesia memiliki potensi yang sangat tinggi yaitu sekitar 261 juta penduduk yang tersebar dalam 13.700 pulau, 33 provinsi, 500 kabupaten dengan 58 juta pelajar, 3 juta guru dan 302.097 sekolah (Mendikbud, 2017 \& Bastari, 2016). Secara umum tantangan pendidikan di Indonesia yang menjadi prioritas adalah meningkatkan minat siswa dalam belajar (Tobias, 2014), peningkatan kualitas guru, peningkatan efektivitas dan efisiensi pembelajaran berbasis media (OECD \& ADB, 2015 \& Mendikbud, 2017). Media pembelajaran dalam kegiatan belajar mengajar merupakan kunci sukses dalam pendidikan (Smaldino, 2014).

Pengembangan media berbasis android sangat berkembang pesat akhir-akhir ini (Donner, 2008 \& Joorabchi, 2016). Hal ini dikarenakan popularitas smartphone android yang digunakan dikalangan masyarakat, terlebih mahasiswa. Berdasarkan survey dilapangan diperoleh data bahwa 96\% masyarakat Indonesia menggunakan smartphone, hal inilah yang menjadi pendorong bagi para pengembang perangkat lunak untuk mengembangkan aplikasi berbasis android. Beberapa pengembang telah mengembangkan aplikasi berbasis android dalam bidang pendidikan, diantaranya adalah Muyaroah (2017) telah mengembangkan Media Pembelajaran Berbasis Android dengan menggunakan Aplikasi Adobe Flash CS 6 pada Mata Pelajaran Biologi, media yang dia kembangkan memberikan pengaruh yang positif terhadap hasil belajar. Selanjutnya Susilo (2017) telah mengembangkan media pembelajaran berbasis android pada pembelajaran wheel alighment memiliki dampak yang posistif terhadap hasil belajar siswa SMK Surakarta. Frediana (2016) telah mengembangkan perangkat pembelajaran berbasis android dalam pelajaran teknologi dasar otomotif, yang memberikan pengaruh positif terhadap hasil belajar dan respon siswa.

Musahrain (2016) mengembangkan perangkat pembelajaran berbasis android pada pembelajaran bahasa inggris yang juga memberikan dampak posistif pada hasil belajar siswa. Dalam bidang matematika diperguruan tinggi belum banyak dilakukan pengembangan perangkat pembelajaran berbasis android, terlebih dalam mata kuliah Teori Ring. Yuniati (2012) meneliti tentang pengembangan bahan ajar struktur aljabar 
berbasis tugas resitasi untuk mahasiswa Universitas Islam Negeri Suska Riau. Hasil penelitiannya menunjukkan bahwa penggunaan perangkat pembelajaran struktur aljabar berbasis tugas resitasi memberikan hasil validasi yang sangat baik meskipun implementasi dari bahan ajar ini belum dilakukan. Kekurangan hasil penelitian ini adalah pengembangan yang dilakukan masih konvensional.

Selanjutnya penelitian yang dilakukan oleh Elah (2008) yaitu mengembangkan perangkat pembelajaran berbasis komputer dan tugas terstruktur dapat memberikan rangsangan bagi mahasiswa untuk belajar sehingga dapat menggali kemampuan kreatif dan daya matematiknya. Kelebihan penelitian ini adalah adanya inovasi perangkat pembelajaran berbasis komputer sehingga mahasiswa memperoleh suasana baru dalam perkuliahan struktur aljabar. Tetapi kekurangan penelitian ini adalah keterbatasan akses mahasiswa terhadap media komputer, sehingga mahasiswa belum memiliki akses yang fleksible terhadap bahan ajar ini. Mahasiswa hanya dapat mengakses ketika berada dikampus.

Fadli (2010) mengembangkan bahan ajar struktur aljabar berbasis website memberikan efek positif terhadap motivasi dan hasil belajar mahasiswa. Selanjutnya penelitian yang dilakukan oleh Ellis (2015) yaitu mengembangkan bahan ajar struktur aljabar dengan strategi REACT dapat meningkatkan minat belajar serta hasil belajar mahasiswa. Kekurangan penelitian ini adalah belum adanya inovasi pemanfaatan IT sebagai media pembelajaran, mengingat muatan dari mata kuliah struktur aljabar yang sangat abstrak diperlukan inovasi yang dapat meningkatkan gairah mahasiswa dalam belajar.

Menurut Elah (2008) dan Yuniati (2012) Mata kuliah Struktur Aljabar adalah suatu mata kuliah yang berisi konsep-konsep abstrak, sehingga mahasiswa seringkali mendapat kesulitan dalam mempelajarinya. Untuk mengatasi permasalahan tersebut, peneliti akan mengembangkan media pembelajaran berbasis android, pengembangan yang akan dilakukan peneliti menggunakan pendekatan pembelajaran berbasis smartphone android. Smartphone yang merupakan perangkat telepon genggam (handphone) didalamnya terdapat fungsi PDA (Personal Digital Assistant) yang dapat bekerja layaknya komputer. Berdasarkan observasi peneliti $100 \%$ mahasiswa prodi pendidikan matematika menggunakan Smartphone android, sehingga hal ini menjadi peluang untuk menjadikan media ini sebagai media pembelajaran. Android 
merupakan sistem operasi open source sehingga sangat memudahkan pengguna dalam mendapatkan aplikasinya.

Darmawan (2012) menjelaskan bahwa mobile learning merupakan salah satu pilihan solusi untuk layanan pembelajaran yang dapat dilaksanakan dimanapun dan kapanpun. Mobile learning mempunyai cakupan yang luas karena menggunakan jaringan selular komersial, dapat diintegrasikan dengan sistem e-learning dan sistem layanan pesan instan. Melalui mobile learning mahasiswa dapat mengakses materi pembelajaran dan informasi dimanapun dan kapanpun, tidak perlu menunggu waktu tertentu untuk belajar. Darmawan (2012) menjelaskan perkembangan mobile learning diawali oleh penetrasi perangkat mobile yang sangat cepat. Banyaknya perangkat mobile lebaih banyak daripada PC, serta pengoperasiannya lebih mudah dibandingkan PC.

Attewell (2009) menyatakan bahwa teknologi yang digunakan untuk mobile learning adalah teknologi genggam seperti personal digital assitans (PDAs), mobile phone, smartphone, multimedia player, ultramobile PC dan lain-lain. Dari berbagai teknologi tersebut salah satu perangkat yang dapat dimanfaatkan untuk pembelajaran yang mobile adalah smartphone. Smartphone berkembang saat telepon selular semakin kecil dan mempunyai lebih banyak fitur dan kegunaan (Woodil, 2010).

Penggunaan IT dalam pembelajaran dapat menciptakan atmosfer pembelajaran dimana mahasiswa dapat terlibat aktif dalam pembelajaran. Perkembangan IT yang begitu cepat memberikan banyak kemudahan dalam mengakses media pembelajaran. Media pembelajaran harus dapat digunakan secara masal dan mudah digunakan dalam berbagai tempat (Arsyad, 2002). Salah satu perangkat pembelajaran yang mudah diakses kapanpun dan dimanapun adalah media berbasis mobile learning. Mobile learning mempunyai keunggulan diantaranya adalah biaya tidak mahal, mendukung konten multimedia, serta dapat dimanfaatkan dimana saja. Perangkat mobile dapat terhubung kejaringan kapan saja dan dimana saja, lebih fleksibel dalam mengakses sumber belajar (Woodill, 2010).

Pengembangan perangkat pembelajaran berbasis mobile dapat menciptakan pembelajaran yang inovatif (Yuntoto, 2015). Salah satu sistem operasi mobile yang paling populer adalah android. Android merupakan sistem aplikasi opensource sehingga relatif lebih mudah untuk mengembangkan aplikasi. Media pembelajaran berbasis android dapat meningkatkan ketertarikan 
mahasiswa dalam belajar. Kemudahan dalam mengakses media pembelajaran ini dapat membuat mahasiswa lebih sering membuka kembali materi diluar jam kuliah.

\section{Metode}

Penelitian ini dilakukan di Program studi pendidikan Matematika Universitas Muhammadiyah Gresik yang beralamat di Jalan Sumatra No 101 Gresik Kota Baru, Jawa Timur, Indonesia. Subjek dari penelitian ini adalah mahasiswa program studi pendidikan matematika Universitas Muhammadiyah Gresik, ahli media dan ahli materi. Sedangkan objek dari penelitian ini adalah aplikasi media pembelajaran.

Penelitian ini adalah penelitian pengembangan dengan mengadaptasi dari langkah-langkah penelitian dan pengembangan yang dikembangkan oleh Borg and Gall (2003) dengan beberapa pembatasan. Langkah penelitian dan pengembangan yang dilakukan oleh peneliti dibagi menjadi enam langkah penelitian yaitu: 1) Tahap studi pendahuluan; 2) Tahap perencanaan pengembangan produk. ; 3) Tahap pengembangan produk; 4) Tahap validasi dan uji coba; 5) Diseminasi dan implementasi; 6) Finalisasi produk.

Selanjutnya, teknik pengumpulan data yang digunakan adalah interview, observasi dan penyebaran kuesioner. Interview dan observasi digunakan untuk mendapatkan gambaran produk yang akan dikembangkan agar sesuai dengan karakteristik pengguna. Sedangkan kuesioner digunakan untuk mendapatkan data pendapat dari ahli media, ahli materi dan siswa selaku pengguna terhadap produk yang telah dikembangkan. Ahli materi dan ahli media ini digunakan untuk uji validasi yang masing-masing terdiri dari 2 dosen program studi pendidikan matematika dan 2 dosen program studi teknik informatika. Sedangkan tahap uji coba dilakukan pada 30 mahasiswa yang menempuh mata kuliah Teori Ring di program studi pendidikan matematika.

Data yang telah diperoleh kemudian dilakukan analisis. Teknik analisis data pada tahap validasi media adalah sebagai berikut:

Tabel 1 kriteria kevalidan media

\begin{tabular}{cl}
\hline Rata-rata Skor & \multicolumn{1}{c}{ Klasifikasi } \\
\hline $\bar{x}>4,2$ & Sangat valid \\
$3,4<\bar{x}<4,2$ & Valid \\
$2,6<\bar{x}<3,4$ & Cukup Validf \\
$1,8<\bar{x}<2,6$ & Kurang valid \\
$\bar{x} \leq 1,8$ & Sangat kurang valid \\
\hline
\end{tabular}

Sedangkan data yang diperoleh pada saat uji coba dianalisis dengan mengacu pada table 2 berikut:

Tabel 2 kriteria kelayakan media

\begin{tabular}{cl}
\hline Rata-rata Skor & \multicolumn{1}{c}{ Klasifikasi } \\
\hline $\bar{x}>4,2$ & Sangat baik (SB) \\
$3,4<\bar{x}<4,2$ & Baik (B) \\
$2,6<\bar{x}<3,4$ & Cukup (C) \\
\hline
\end{tabular}


$1,8<\bar{x}<2,6 \quad$ Kurang $(\mathrm{K})$

$\bar{x} \leq 1,8 \quad$ Sangat kurang (SK)

Data yang diperoleh dari dua kuesioner diatas, kuesioner ahli materi dan media, dan kuesioner dari siswa pada saat uji coba, akan menunjukkan kevalidan dan kelayakan Terima App yang telah dikembangkan sebagai media pembelajaran Teori Ring.

\section{Hasil dan pembahasan}

\section{Hasil Analisis Kebutuhan}

Analisis awal yang dilakukan dalam penelitian ini adalah melakukan analisis kebutuhan. Dari hasil analisis diperoleh data bahwa calon pengguna yaitu mahasiswa semester 6 prodi Pendidikan Matematika memiliki karakteristik: a) banyaknya pengguna adalah sebanyak 30 mahasiswa yang terdiri dari 4 mahasiswa laki-laki dan 26 mahasiswa perempuan; b) Rata-rata usia calon pengguna adalah 20 tahun; c) $100 \%$ pengguna memiliki smartphone android; d) Karakteristik calon pengguna rata-rata lahir pada tahun 1998. Calon pengguna ini termasuk dalam generasi iGeneration atau generasi internet, yang mampu mengaplikasikan semua kegiatan dalam satu waktu misalnya dalam waktu yang bersamaan menggunakan ponsel, browsing dengan PC serta mendengarkan musik menggunakan headset. Setiap hal yang dilakukan sebagian besar berhubungan dengan dunia maya.
Selanjutnya adalah hasil analisis materi yang akan dikembangkan. Materi yang akan dikembangkan terdiri dari 6 topik yaitu Ring dan subring; Ideal dan Ring factor; Daerah Integral; Field; Homomorfisme Ring; dan Ring polynomial.

\section{Hasil pengembangan produk}

Berikut tampilan Terima App yang telah dikembangkan:
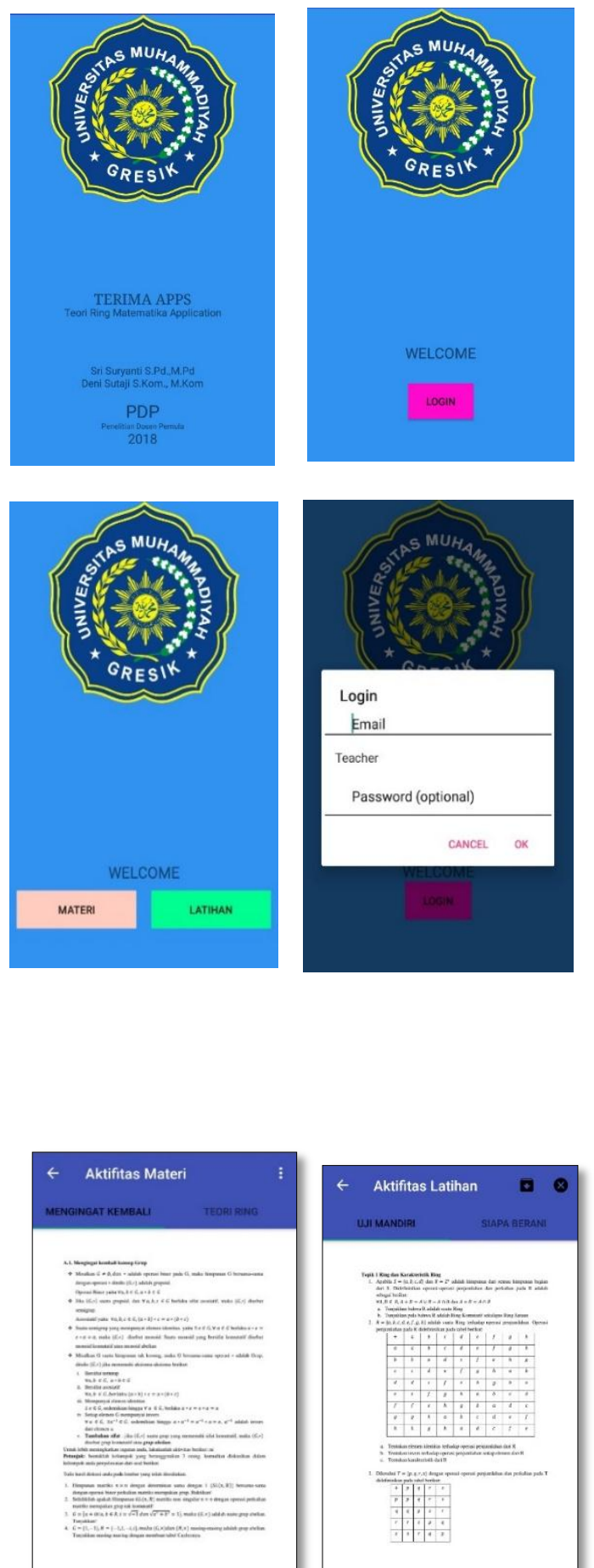
Gambar 1. Tampilan media

\section{Analisis Data}

Analisis data dilakukan untuk menganalisis data yang diperoleh dari hasil tes validasi dan tes uji coba. Skor yang diperoleh dari tes validasi oleh ahli media dan ahli materi, dihitung skor rataratanya dengan menggunakan rumus:

$$
\bar{x}=\frac{\sum x}{n}
$$

Dengan $\bar{x}=$ skor rata - rata

$$
\begin{aligned}
& \qquad \sum x=\text { jumlah skor } \\
& \qquad n=\text { banyaknya penilai } \times \text { skor maksimal } \\
& \text { hasil perhitungan skor rata-rata dari masing- } \\
& \text { masing ahli disajikan pada table } 3 \text { : } \\
& \text { Table } 3 \text { hasil penilaian ahli media dan ahli }
\end{aligned}
$$

\begin{tabular}{|c|c|c|c|}
\hline Ahli media 2 & 39 & 3,9 & Valid \\
\hline Ahli materi 1 & 41 & 4,1 & $\begin{array}{l}\text { Sangat } \\
\text { valid }\end{array}$ \\
\hline Ahli materi 2 & 44 & 4,4 & Valid \\
\hline
\end{tabular}

Table 3 diatas, menunjukkan hasil penilaian dari ahli media maupun ahli materi. Dari dua ahli media, keduanya memberikan penilaian diatas 3,4 sehingga dapat disimpulkan media yang dikembangkan adalah valid, begitu pula dengan ahli materi, keduanya memberikan penilaian dengan skor rata-rata diatas 4, sehingga dari sisi konten materi dapat dikatakan bahwa media yang dikembangkan adalah valid.

Selanjutnya data yang diperoleh pada tahap uji coba, data dikonversi sesuai dengan table 2. Uji coba ini dilakukan secara terbatas kepada 10 mahasiswa dari total 30 masing ahli disajikan pada table 3: materi

\begin{tabular}{clcl}
\hline Validator & $\begin{array}{c}\text { Total } \\
\text { skor }\end{array}$ & $\begin{array}{c}\text { Rata- } \\
\text { rata } \\
\text { skor }\end{array}$ & Kategori \\
\hline Ahli media 1 & 43 & 4,3 & $\begin{array}{l}\text { Sangat } \\
\text { valid }\end{array}$ \\
\hline
\end{tabular}

mahasiswa yang menempuh mata kuliah Teori Ring. Kuesioner untuk mahasiswa ini terdiri dari 23 item pertanyaan dengan rincian: 12 aspek aturan media, 5 aspek CAI media dan 6 aspek relevansi materi. Hasil konversi data tersebut disajikan pada table 4 berikut:

\begin{tabular}{lcccccc}
\hline Responden & $\begin{array}{c}\text { Aturan } \\
\text { media }\end{array}$ & $\begin{array}{c}\text { CAI } \\
\text { media }\end{array}$ & $\begin{array}{c}\text { Relevansi } \\
\text { materi }\end{array}$ & $\begin{array}{c}\text { Skor total } \\
\text { Skor rata- } \\
\text { rata }\end{array}$ & Kategori \\
\hline Siswa 1 & 48 & 21 & 24 & 93 & 4.0 & Baik \\
Siswa 2 & 49 & 22 & 24 & 95 & 4.1 & Baik \\
Siswa 3 & 50 & 22 & 25 & 97 & 4.2 & Baik \\
Siswa 4 & 47 & 22 & 26 & 95 & 4.1 & Baik \\
Siswa 5 & 48 & 23 & 26 & 97 & 4.2 & Baik \\
Siswa 6 & 49 & 23 & 26 & 98 & 4.3 & Sangat baik \\
Siswa 7 & 50 & 23 & 26 & 99 & 4.3 & Sangat baik \\
Siswa 8 & 50 & 20 & 25 & 95 & 4.1 & Baik \\
\hline
\end{tabular}




\begin{tabular}{lllllll}
\hline Siswa 9 & 47 & 23 & 25 & 95 & 4.1 & Baik \\
Siswa 10 & 47 & 21 & 24 & 92 & 4.0 & Baik \\
\hline
\end{tabular}

Hasil dari penilaian siswa terhadap media

Teori Ring yang telah dikembangkan, $80 \%$ siswa memberikan skor rata-rata dengan kategori "baik", sedangkan sisanya yairu $20 \%$ siswa memberikan skor rata-rata dengan kategori "sangat baik". Sehingga dapat disimpulkan bahwa media Teori Ring yang telah dikambangkan layak untuk digunakan.

\section{Simpulan dan saran}

Kesimpulan yang dapat diambil dari hasil penelitian ini adalah media "Teori Ring Mobile application (Terima App)" ini valid dan layak untuk digunakan sebagai media pembelajaran pada perkuliahan Teori Ring. Media ini memiliki aksesibilitas yang tinggi, karena siswa dapat mengakses secara offline setelah mereka menginstall dari aplikasi ini. Hasil penilaian dari ahli media dan ahli materi menunjukkan bahwa media Terima App ini layak untuk digunakan, begitu pula dengan hasil penilaian mahasiswa.

Untuk penelitian selanjutnya, kami menyarankan untuk menambahkan tampilan animasi dan simulasi sehingga siswa lebih interaktif dalam pembelajaran.

\section{Ucapan terimakasih}

Kami megucapkan terimakasih yang sebesar-besarnya kepada DRPM Kemristekdikti yang secara penuh memberikan dana untuk penelitian ini.

\section{Referensi}

A. Kurniawan, I. Riadi, and A. Luthfi, “ Forensic analysis and prevent of cross site scripting in single victim attack using open web application security project (OWASP) framework," $J$. Theor. Appl. Inf. Technol., vol. 95, no. 6, pp. 1363-1371, 2017

Attewell, Jill., Savill-Smith, Carol. \& Douch, Rebecca. (2009). The impact of mobile learning Examining what it means for teaching and learning. London: LSA.

Bastari, Indonesia Education Statistics In Brief 2015/2016, vol. I, no. 1 . Kementerian Pendidikan dan Kebudayaan, 2016.

Borg \& Gall,2003. Education Research. New York : Allyn and Bacon

Bush, W. S \& Greer, A. S. 1999. Mathematics Assessment. Reston:NCTM

Darmawan, Deni. (2012). Teknologi Pembelajaran. Bandung: Remaja Rosdakarya. 
Degeng. 2004. Strategi pembelajaran mengorganisasi isi dengan model elaborasi. Malang:IKIP dan IPTDI.

Elah, Nurlaelah dkk. 2009. Pembelajaran Mata Kuliah Struktur Aljabar Yang Berbasis Komputer dan Tugas Terstruktur Untuk Menggali Potensi Kreatif Dan Daya Matematik Mahasiswa. Makalah yang diseminarkan dalam Seminar Nasional Aljabar, Pengajaran Dan Terapannya dengan tema Kontribusi Aljabar dalam Upaya Meningkatkan Kualitas Penelitian dan Pembelajaran Matematika untuk Mencapai World Class University yang diselenggarakan oleh Jurusan Pendidikan Matematika FMIPA UNY Yogyakarta pada tanggal 31 Januari 2009.

Fadillah, Syarifah \& Jamilah. 2016. Pengembangan Bahan Ajar Struktur Aljabar Untuk Meningkatkan Kemampuan Pembuktian Matematis Mahasiswa. Cakrawala Pendidikan, Februari 2016, Th. XXXV, No. 1.

Fadli. 2010. Pengembangan bahan ajar struktur aljabar berbasis website. Jurnal Persperktif Ilmu Pendidikan Vol 22 Th XIII Oktober 2010
Hosnan, M. 2014. Pendekatan saintifik dan kontekstual dalam pembelajaran abad 21. Bogor:Ghalia Indonesia

J. Tobias, J. Wales, and E. Syamsulhakim, TOWARDS BETTER EDUCATION Indonesia's promising path, no. July.

Kemdikbud, IKHTISAR

DATA PENDIDIKAN TAHUN 2016/2017. 2017

London: development progress, 2014.

Majid. 2014. Strategi pembelajaran. Bandung: PT Remaja Rosdakarya

Mintowati. 2003. Panduan penulisan buku ajar. Depdikbud:Jakkarta

NCTM. 2012. Principle and standards for school mathematics. United States of America: National Council of Teachers of Mathematics.

OECD and ADB, Education in Indonesia: Rising to the Challenge, vol. 20, no. 15. 2015.

Panggabean , Ellis.M. 2015. Pengembangan Bahan Ajar Dengan Strategi React Pada Mata Kuliah Struktur Aljabar I Di Fkip Umsu. Jurnal EduTech, Vol. 1 No 1

R. Penwarden, THE RISE OF THE SMARTPHONE. FLUID SURVEYS, 2016.

Rita C. Richey, J. D.K., Wayne A Nelson. 2009.

Developmental 
Research:Studies of Instructional

Design and Development.

Satyaputra. 2014. Beginning Android

Programming with ADT Budle.

Jakarta:Alex Media komputindo.

ScientiaMobile, "Mobile Overview Report

January - March 2017," no. March, 2017.

Shadiq, fajar. 2004. Pemecahan masalah,

Penalaran dan Komunikasi. Makalah

pengembang Matematika SMA

Yogyakarta.

Sugiono. 2011. Metode penelitian kuantitatif, kualitatif, dan $R \& D$.

Bandung:Alfabeta

Suryanti, Sri. 2016. Modul Teori Ring.

Gresik: Universitas Muhammadiyah Gresik

Suryanti, Sri. 2015. Modul Teori Grup.

Gresik: Universitas Muhammadiyah

Gresik
Syaodih Sukmadinata. 2006. Metode Penelitian Tindakan. Bandung: Remaja Rosda Karya

Van den Akker J. 1999. Principles and Methods of development Research. Dortrech: Kluwer Academic Publishers.

Van den Akker J. 2006. Educational Design Research. London and New York: Routledge.

Yuniati, Suci. 2012. Pengembangan Bahan Ajar Struktur Aljabar Berbasis Tugas Resitasi Untuk Mahasiswa Universitas Islam Negeri Suska Riau. Gamatika, Vol. III No.1 Nopember 2012

Woodill, G. (2010). The mobile learning edge: Tools and technologies for developing your teams. McGraw Hill Professio 